\section{ABCS}

How to cite this article: Zilli et al.

Knowledge of the self facing the experience of illness by cancer and palliative care. ABCS Health Sci. 2021;46:e021211. https:// doi.org/10.7322/abcshs.2020053.1502

Received: Jun 05, 2020

Revised: Sep 01, 2020

Approved: Sep 22, 2020

Autor para correspondência: Francielly Zilli - Universidade Federal de Santa Catarina - Campus Reitor João David Ferreira Lima - Bairro Trindade - CEP: 88040-900 Florianópolis (SC), Brazil -

E-mail: franciellyzilli.to@gmail.com

Declaration of interests: nothing to declare Funding: CAPES

This is an open access article distributed under the terms of the Creative Commons Attribution License

(C) 2021 Zilli et al.

\title{
Knowledge of the self facing the experience of illness by cancer and palliative care
}

\author{
Francielly Zilli', Stefanie Griebeler Oliveira², Franciele Roberta Cordeiro², \\ Juliana Graciela Vestena Zillmer² \\ ${ }^{1}$ Universidade Federal de Santa Catarina (UFSC) - Florianópolis (SC), Brazil. \\ ${ }^{2}$ Universidade Federal de Pelotas (UFPel) - Pelotas (RS), Brazil.
}

\begin{abstract}
Introduction: The illness of an oncological disease provides experiences capable of modifying the body and the subjects' ways of life. Objective: To analyze how the knowledge of the self occurs facing the experience of illness by cancer and palliative care. Methods: This is a qualitative case study research based on postcritical theories, specifically in Foucault Studies. The participants were six patients who were experiencing cancer and palliative care, linked to a home hospitalization service. The data were collected from March to June 2018, based on open interviews, participant observation, and speech instigation through the use of occupational therapist therapeutic activities. The analysis occurred based on problematizations. Results: From the statements, different ways of getting sick were identified, from diagnosis to their approach to death, causing changes in the body, way of living, and in the perception of oneself from a life-threatening disease. Conclusion: Finally, we concluded that different ways of experiencing cancer and palliative care provided different modes of subjectivation. The lack of self-recognition was confronted by bodily changes and consequently by limitations, so the way this experience was lived reflected in the way they thought about the end of life.
\end{abstract}

Keywords: palliative care; neoplasms; life change events; qualitative research; occupational therapy; oncology nursing.

\section{INTRODUCTION}

The constitution of the body occurs by the lived events, that is, the spaces through which it circulated and the pieces of knowledge with which it had contact. Thus, the is re-signified through words, gestures, looks, spaces that occupy and lives, consequently the things that happen, the experiences ${ }^{1}$.

The experience of cancer and palliative care can be understood as an event. Here, an event is understood as discursive pronouncements, capable of producing relationships of forces that constitute the body-event ${ }^{2}$. The concept of the event, in the Foucault Studies, is the "censure that breaks the moment and disperses the subject into a plurality of possible positions and functions ${ }^{3}$.

The event has four meanings: historical rupture, historical regularity, present, and work of happening ${ }^{4}$. Here, we are staying with historical regularity, where the event of experience of illness by cancer is seen as a discursive event because it is related to the characteristics that form entire discourse on falling ill by cancer and will be identified in the participant's speeches since we understand that they were subjectivized by such 
discourse. It is the effects of this historical regularity associated with the oncological illness event that produces the oncological subject.

When the history of cancer is told, it is displayed as being able to consume the body slowly and making it opaque. Cancer is understood not as a disease of time, but of space, as one that spreads throughout the body and modifies it, thus being reported by metaphors 5 .

The event of the illness is current; it breaks now the whole life history, thus being the historical regularity of cancer experienced by the subjects in the presence of their lives ${ }^{6}$. This rupture of the now allows one to live an experience that robs the subject of oneself, capable of making it different from what it was before the event of getting sick. In this way, we understand the experience as something that challenges and goes beyond limits ${ }^{7}$. The experience - here related to the event or experience of illness - is not necessarily related to the founding subject, but rather to who overcomes the subject and its foundation, that is, removes one from oneself, suppresses the subject preventing it from remaining the same ${ }^{8}$.

This event - of illness - throughout life which one seeks at that moment to understand refers us to the words about the experience as "the passage of existence, the passage of a being that has no essence or reason or ground, but simply 'exists' in an always singular, finite, immanent, contingent form"

We believe that by giving space to express oneself in the face of approaching death, we can recognize the demands of the subjects and thus offer a qualified practice that allows the performance care of the self and not just clinical care.

Thus, this study aimed to analyze how the knowledge of the self occurs facing the experience of illness by cancer and palliative care.

\section{METHODS}

This paper describes some results of a dissertation entitled "Care of the self of patients with advanced cancer disease mediated by activities as a clinical resource"10. It is a qualitative case study research based on post-critical theories, specifically in Foucault Studies.

The study included six patients with advanced cancer out of the possibility of a cure in palliative care, accompanied by a home hospitalization service of a University Hospital in southern Brazil. Eight patients were invited, of which only one refused to participate in the research because he believed that his clinical condition prevented his participation. The data was collected from March to June 2018. For the selection of the participants, we counted on the health team indication according to the following inclusion criteria: age equal to or above 18 years old and with verbal communication conditions. Considering that there are many descendants of Pomeranians in the region; as exclusion criteria, those who did not speak Portuguese could not participate.

Initially, the participants were contacted by telephone when the researcher - lead author - identified herself, pointing out the main objectives and requesting permission to make a home visit to formalize the invitation. We invited the participants and clarified the Informed Consent. To preserve the identity of the participants, each one chose the name of a bird.

Regarding the data collection, we conducted open interviews, which totaled 25 hours of audio records, directed by the performance of therapeutic activities and resulting in 22 meetings ( 03 with Cardeal and Sabiá, 04 with Papagaio and Beija-flor, 05 with Águia and 03 with Quero-Quero). Also, participant observation occurred in all meetings concomitant with the interview and was performed by the lead author. The research was carried out in the participants' homes since they were in-home care, so weekly telephone contact was made to confirm the meeting, which took place in the living room, bedroom or kitchen, with the presence of family members according to the conditions and wishes of the participants.

For data collection, we used the therapeutic activities of the occupational therapist. This perspective is sustained in the post-critical theories because it is believed that it is possible in this area to use all possible resources to have greater access to the object and the paths traveled concerning what we are investigating ${ }^{11}$. The records were made using a voice recorder, and field notes were taken after each meeting.

The information recorded and coming from observations were transcribed into a document in the Microsoft Word program to organize and for further analysis. Later, The Ethnography 6.0 program was used in the demo version, starting the coding and categorization process ${ }^{12}$.

In this way, the approach of the speeches was made with these Foucault concepts: experience, subject, and body. The code of the experience was divided into the first moment - diagnosis experience-related; second and third-moment experience - highlighting the complications, the new moments of rupture that were experienced by the subjects after diagnosis. To discuss the codification of the speeches, a textual analysis was carried out based on problematizations; thus, the following questions were made: "How do patients report their experience of illness?" "How do they experience changes?", "How do they perceive themselves in the event of illness?".

The research was approved by the Research Ethics Committee, under register No. 2,513,679, as recommended by the Brazilian regulation.

\section{RESULTS}

Four women (Beija-flor, Papagaio, Águia, Sabiá) and two men (Cardeal and Quero-Quero) participated in the research. 
Each of these participants was experiencing life with a lifethreatening disease: cancer. The ways of reporting how they "became subjects with a life-threatening disease" were different. Each one assigns characteristics, nomenclatures, and personal metaphors to the disease. Some called it "cancer" in the first meeting; others said goodbye without giving a name, but not without attributing meaning. Each of the reports can be seen as a backdrop for the constitution of this ill subject, which carries with them speeches that constituted them throughout their life and that enabled them to experience the event of the diagnosis the way it was.

Here, the experience of cancer as an event allowed the identification of three moments: diagnosis, complications, proximity to death. For the presentation of the results, three categories of analysis were constructed: (1) experiences facing a cancer diagnosis, where it is reported how participants received the cancer diagnosis, the path is taken between the unknown, and the recognition of the first signs of alteration of the body in the face of the experience of falling ill; (2) The experience of illness after cancer diagnosis, where it is reported how the experiences of falling ill subjectify the subject changing the ways of living; and (3) between living and "death as the only certainty" which addresses how subjects understand death and how they are subjective by the approach to the end of life in the face of the experience of falling ill.

\section{Experiences facing a cancer diagnosis}

From escaping the diagnosis to searching for help. This is how Cardeal experienced the new of the diagnosis and all the therapeutic needs: I did the colonoscopy, and then it came out that I had a nodule in my rectum. Then I began to treat myself, I started preparing myself spiritually. [...] The doctor said, "Cardeal, you are going to have to go through surgery, but you are not obliged. But if you do not want to, it is your call. There is only one thing, it is going to burst, you are going to throw up feces, you are going to suffer a lot more". Then I said: "Doctor, I have come prepared - I give my hands first to God, and second to you. Do what has to be done." [...] I even ran away, I should have done this [pointed to the colostomy bag], and at that moment I did not accept it, so I say, no, I'll take a break, I'll prepare myself well. [...] A thought came in my mind that if I were going to do it, my life would end (Cardeal).

Unlike Cardeal, Sabiá was less communicative by the end of her life. I keep thinking about how fast [...] I started with a lot of bleeding. Then I went through eight doctors, had exams and nothing [...] then when they found out I was already in level four, very advanced. [...] When I came home, I felt dumbfounded. In the beginning, I could not stay alone, I had to have someone always with me, I cried a lot (Sabiá).

In the field notes, Field Note - April 18, 2018, Beija-flor was reported as "different: rational optimism" due to the objectivity when talking about her experience with the disease. Initially, the search for the diagnosis became a long and exhaustive walk.
The care of the other and the non-recognition of self, the loss of self in the face of the unknown, are perceptible in the following excerpt: My mother died in May. I started feeling the pain in November. [...] I did not pay much attention, you know, I thought it was a little sadness [...] Sometimes at noon I could not have lunch. [...] I walked in the dark. I have been a lot in the Emergency, taking medication for pain, for vomits, and then they always sent me away from the same way. [...] So when I discovered the disease [...] I face it as it has to be. [...] The tomography showed a tumor in the ovary, metastasis from the root that is in the stomach. [...] My diagnosis is severe, considering the size of the metastasis in my ovary, added to the tumor in the stomach, plus the long period without treatment. Also, rib metastasis appeared. So, it was a thing that brought everything (Beija-flor).

In one of the meetings with Papagaio, a 43-year-old woman, a fictitious report of a 49 -year-old woman was presented. The woman reported how it was to receive the breast cancer diagnosis. Papagaio showed she disliked the stories associated with the reports of people with cancer: The story of the disease did not go very well in my life. My illness was just the flu. [...] In fact, I had never had much involvement with this cancer disease because I thought that people were too exaggerated when they said someone had died due to cancer. They never told a happy story about how the girl had cancer, but she's fine, with her life ahead of her, working, studying. [...] There is no cure for this disease! They were just unfortunate stories. No one was able to tell the good part after the treatment (Papagaio).

The change in the way of living and the interruption of certain desires were also presented by Quero-Quero: When we were going to start enjoying [life], it [the illness] came "go slow" [laughs]. I wish I could enjoy it more. [...] Each one has their own story of having to cross that crossroads. Even though it's a disease that everyone is afraid of, I have been fighting it for about ten years. Theoretically, I can say that I was prepared, but I was not. It could happen to me, and it happened, [voice embargoed], [...] it was my way. I could have avoided a lot of things, took a road a little better (Quero-Quero).

\section{Experience of illness after a cancer diagnosis}

As the sick subject recognizes themselves from the first moment of the diagnosis experience, they also experience new challenges and thus come into contact with new problems, such as physical changes like hair loss, nausea, and tiredness, which configure here the second moment of this event that is to get sick: I stayed five years without receiving chemotherapy in the body, and now again, this same function. [...] I have all the symptoms. I lost hair, I have intense nausea daily. There was a month that I got seasick from the start of chemo to the next one. Imagine 21 days! Chemo helps you on the one hand, but before that, it knocks you down. [...] I feel a lot of pain, then I get tired, I feel shortness of breath, then there is no way to move around and do my stuff (Papagaio). 
For Beija-flor, unlike the other participants, although illness by cancer is something serious, it was from the diagnosis that she recognized herself: After the discovery of the disease, although it is a serious disease that causes many pains, many things to go throu$\mathrm{gh}$, I felt much more relieved, [...] because I took a weight off from inside myself. [...] Surely, I feel much stronger, much more determined, because I know what I am fighting for, and I know the path I have to travel. So in this path that I traveled until I reached the diagnosis, I suffered much more. What's left is what I started to be after the diagnosis. (Beija-flor).

\section{Between living and "death as the only certainty"}

When asked about the end of their lives, the participants understood death as a condition of possibility: If God has given me until now, if it is for me to lose the battle, I will go prepared, I will go firm, I will not worry about feeling like "uh I will die" because I think like this our life here is a passage [...] only He [God] knows what will happen to me from now on. [...] What I think about that [death], is the only thing that we have for sure in life [...] I'm prepared for whatever He decides, [...] if He gives me a year, it's okay; if He gives me ten, better. But may He let me be healthy, may I be able to do what I like. He knows what He is doing, it is fine if I am either deserving or not. (Cardeal).

When prompted to think about their deaths, how it might happen, or what they might leave behind, the participants reported how they visualize this moment: $A$ song that I like very much, that I am going to take with me, and that I have been bringing into my life since I was a little girl... I am going to be cremated, and I want them to play it because there are people who are afraid to talk about death, and I am not afraid. I want Limelight by Charles Chaplin. [...] I said it already, it is all planned, everybody knows. [...] We have to plan because the most certain thing in this life is death. [...] When I am cremated, I want that song on my cremation. (Águia).

\section{DISCUSSION}

In the first moment of the experience of illness, we point out the non-recognition of oneself by the event of falling ill that modifies the subject and his way of living. The changes of a body and its actions occurred due to the non-recognition of the self before illness and the movement of turning the gaze and care to the other and not to oneself. We also observed difficulties in talking about the cancer experience due to this lack of self-recognition that occurs in the face of the event.

The event that constituted the body in this or another way - the body giving a sign that something was wrong - involved tiring searches for a diagnosis, which generated ambiguities: on the one hand the desire to know what was happening and on the other the desire to wake up from a dream, or nightmare. Such difficulties were inscribed in these bodies and constituted the subjects of the limitations from the moment they began to share stories of pain and losses with family members.

The experience of illness by cancer can be considered a threat to self-knowledge, confronting patients with their existence, and the struggle to prepare for finitude. The awareness of living with a life-threatening disease is mainly perceived by the significant changes that occur in the body, relationships, and social roles. Thus, the experience is considered multidimensional, requiring patients a nonlinear movement to face the experiences of illness and thus occupy spaces that offer different ways of living this event ${ }^{13}$.

The participants' reports point out that the experience of falling ill with cancer is initially manifested by the body and its modifications, which corresponds with the notion of limit experience, that is, the one that "pulls the subject out of himself same", being able to modify it ${ }^{1}$.

The subjects know each other from body images that are constituted through mental images of the body's sensations and visual images that refer to appearance. The experience of falling ill with cancer changes the body scheme, leading the subjects to recognize themselves and be recognized from these changes ${ }^{14}$.

The reports from the experience of cancer as an event bring a possible second event due to the complications caused by both the treatment and the advance of the disease. A study ${ }^{15}$ points out that they are characteristics that signal the presence of the disease and present in some way the reality of the possibility of death.

We are always rediscovering the body, before the different passages of existence; the body, which affects and is affected by these different events, can be seen as "a set of paradoxes, as an enigma, as something unresolved, like something you never fully know"16 p.117. From this, we can understand it as a constant movement of searching for knowledge in the face of each event and each lived experience ${ }^{17}$. A study ${ }^{18}$ points out the moment of diagnosis as discomfort because it is when subjects are forced to change their daily routines and experiences, starting a new journey that is the treatment of cancer.

Through the experience of cancer as an event, after diagnosis, complications arising from the progress of the disease or treatment are related to the proximity of death. We wonder what this experience can announce beyond the complications and modifications. Could they announce what characterizes the clinical framework of the diagnosis of these participants? - a life-threatening disease. How can they know what lifeline they are on after receiving the diagnosis?

Some of these questions can be contemplated by thinking about the experience as different from information. Having information is not the same as being touched, modified, as in the experience ${ }^{8,19}$. Within the experience, we give meaning (or not) to events that are what we can identify in the presented speeches. The meaning attributed to each of the events, the subjectivation of self that occurs 
from the attribution of this meaning, is what characterizes this as an experience ${ }^{19}$.

As the patients begin to have a greater understanding of the disease progression parallel to the distancing from the cure, they direct hope to new plans. They stop talking directly about the cure but start to make projections in desires to live as long as possible, supported by the religious discourse, of the "time that God allows"20.

On the other hand, it is in the creation of spaces to talk about death that psychic elaborations about the experience of the and of life occur. It is in these spaces that feelings, desires, and plans are shared. Thus, the absence of this communication about death can be considered iatrogenic for care ${ }^{21}$.

Giving expressions to the temporality of life can be related to the attribute of hope for a good quality of life. What was identified concerning this attribute is that, when they realize that the prolongation of life is not a possibility, the desire then becomes to live without prejudice to the quality of life. They can continue with strength, doing what they like ${ }^{20}$.

It is based on reflections on living that we can understand dying, that is "nothing happens in the room of the dying. Everything, on the contrary, is distributed by time in life and in each day of that life", that is, it is to understand that thinking about death should not be processed only at the moment of its proximity ${ }^{22}$.

This difficulty in "reaching an agreement" in talking about death and the possibilities of accepting it is pointed out as something catastrophic because it leads us to think about how much life is beyond what we are, that goes beyond us. Thus, we leave marks throughout our lives, and these marks can remain from the people we touch, who subjectivize us and who we also subjectivize ${ }^{16}$.

In this way, we identified the reflections made by the participants, which include the belief that everything has time to happen and it is determined by a "God", demonstrating tranquility in living with the certainty of divine support and in deserving more time in life. We also identified that those who present this vision could also plan death and express their end-of-life desires for those close to them. However, we understand that the place of death in contemporaneity also influences us. In this way, we realize that talking and thinking about death and dying are still issues that frighten the subjects due to the way they understand this process ${ }^{23}$.

A study ${ }^{24}$ indicates the importance of spaces to clarify and prepare the subject for death to reduce suffering and maintain the subject's autonomy during the end-of-life trajectory. Besides, death is understood as a process that involves making decisions and preparing for death, and such characteristics create opportunities for the subjects' active participation during the dying process.

Thinking about death and even more, experiencing the end-oflife process provides several sensations and behaviors that may vary as this event is experienced. By providing space for the subject to recognize himself in the face of illness, we are allowing him to position himself in the face of the disease and making it possible for him to subject himself to being sick differently from the constituted truths of the cancer patient ${ }^{23}$.

Another study ${ }^{25}$ has demonstrated that death is considered a continuity, as something normal and not as something unjustified. For the patients - especially those who are in the early stages of the disease - cancer is seen as a "little point" in life, asserting a certain continuity of the past.

We consider how much the processes of subjectivation that occur throughout living are modifiable and plural; that is, they are not considered ontologically invariable, but associated with acting modes. Thus, we understand that certain discourses direct truths about the subjects and therefore influence their subjectivation $^{16}$; from this, we seek to understand how these subjects are subjectivized in the face of this "new existence". Subjectivity is understood from the reflections made by Foucault throughout his studies, in which he sought to "create a history of the different ways in which, in our culture, human beings become subjects" ${ }^{16}$ p.231.

Thus, we understand that the stories told here are similar to the truths associated with cancer concerning limitations, and bodily changes, however, different subjects experience these truths in different ways, and it is up to health professionals to accept to better contemplate end-of-life care.

\section{Conclusion}

When investigating the experience of cancer as an event, we identified three moments that mobilized the subjects and subjectified them in different ways. Upon receiving the diagnosis, they experienced a lack of recognition of themselves, pointing out the difficulties in accepting the diagnosis as well as the limitations that mobilized and modified them. Over time these subjects start to recognize themselves by the new changes in the body arising from the event of falling ill.

Here, the experience of cancer as an event resulted in the impossibility of a cure, which is supported by a discursive network, that is, supported by the stories that are often told about becoming ill with cancer, moving the subject to think about death due to proximity.

Amid this new experience, and instigated by our meetings, it was possible, more than pointing out how these subjects were perceiving and constituting themselves as subjects suffering from cancer, but to welcome the questions that the illness causes about death and thus to understand the reflections that are made by these subjects when questioned about their finitude.

As a limitation of the study, the choice of participants for a single home care service is pointed out, linked to the same public care network, making it impossible to generalize the findings; the local culture and the family and friends' network, who may subjectivize them in certain ways and not others. 


\section{REFERENCES}

1. Silva M, Furlan R. Corpo, utopia e limite no pensamento de Michel Foucault. Fractal, Rev Psicol. 2019;31(2):111-18. https://doi.org/10.22409/1984-0292/v31i2/5629

2. Almeida JR. Experiência, acontecimento e educação a partir de Foucault. Filogenese. 2013;6(2):48-62.

3. Foucault M. A ordem do discurso. São Paulo: Loyola, 1970

4. Castro E. Vocabulário de Foucault: um percurso pelos seus temas, conceitos e autores. Belo Horizonte: Autêntica, 2009.

5. Sontag S. Illness as Metaphor. The New York Review of Books, 1984.

6. Cardoso IAR. Foucault e a noção de acontecimento. Tempo Social. 1995;7(1):53-66. http://dx.doi.org/10.1590/ts.v7i1/2.85206

7. Loureiro I. Em busca de uma noção de experiência. Ciênc Cult. 2015;67(1):28-31.

http://dx.doi.org/10.21800/2317-66602015000100011

8. Brandão RTP. Experiência e transformação de si: Foucault e a estatização da vida. InterEspaço. 2016;2(4):81-96. http://doi.org/10.18766/2446-6549/interespaco.v2n4p81-96

9. Larrosa J. Tremores: escritos sobre experiência. Belo Horizonte: Autêntica, 2017.

10. Zilli F, Oliveira SG. Cuidado de si de pacientes com doença oncológica avançada mediado pelas atividades como recurso clínico [master's thesis]. Pelotas, Universidade Federal de Pelotas; 2018

11. Paraíso MA. Metodologia de pesquisas pós-críticas em educação e currículo: trajetórias, pressupostos, procedimentos e estratégias analíticas. In: Meyer DE, Paraíso MA. Metodologias de pesquisas pós-críticas em educação. 2 ed. Belo Horizonte: Mazza Edições, 2014; p.25

12. The Ethnograph 6.0. Qualitative data analysis software. Available from: http://www.qualisresearch.com/

13. Willig C, Wirth L. A meta-synthesis of studies of patients' experience of living with terminal cancer. Health Psychology. 2018;37(3):228-37. http://doi.org/10.1037/hea0000581

14. Ferreira RMB, Lemos MF. A mulher e o câncer de mama: um olhar sobre o corpo adoecido. Perspectiva Psicol. 2016;20(1):178-201. https://doi.org/10.14393/PPv20n1a2016-11
15. Oliveira DSA, Cavalcante LSB, Carvalho RT. Sentimentos de pacientes em cuidados paliativos sobre modificações corporais ocasionadas pelo câncer. Psicol Cienc Prof. 2019;39:e176879. https://doi.org/10.1590/1982-3703003176879

16. Foucault M. O sujeito e o poder. in: Foucault M. Ditos e escritos, volume IX: genealogia da ética, subjetividade e sexualidade. Rio de Janeiro: Forense Universitária, 2014

17. Trevisan A, Lazzarotto J, Fiorentim S, Minozzo M, Silva MR Feixe de paradoxos: reflexões sobre o corpo. Entrevista com a professora Denise Bernuzzi de Sant'Anna. Cade CEOM. 2004;17(20):113-31.

18. Pinheiro MS. Me ensina a (sobre) viver com câncer? Uma análise de livros de autoajuda. [dissertation]. Porto Alegre, Universidade Federal do Rio Grande do Sul. Porto Alegre; 2017.

19. Almada L. Psicologia e liberdade: conhecimento do "eu" e das coisas. Fractal Rev Psicol. 2011;23(1):85-98. http://dx.doi.org/10.1590/S1984-02922011000100007

20. Daneault S, Lussier V, Mongeau S, Welle L, Côte A, Sicotte C, et al. Ultimate journey of the terminally ill. Ways and pathways of hope. Can Fam Physician. 2016;62(8):648-56.

21. Lima CP, Machado MA. Cuidadores principais ante a experiência da morte: seus sentidos e significados. 2018;38(1):88-101. https://doi.org/10.1590/1982-3703002642015

22. Ariès P. História da morte no Ocidente: da idade média aos nossos dias. Ed especial. Rio de Janeiro: Nova Fronteira, 2017.

23. Dantas MMF, Amazonas MCLA. The IIIness experience: Palliative care given the impossibility of Healing. Rev Esc Enferm USP. 2016;50(esp):46-52. http://dx.doi.org/10.1590/S0080-623420160000300007

24. Kastbom L, Milberg A, Karlsson M. A good death from the perspective of palliative cancer patients. Support Care Cancer. 2017;25(3):933-9. https://doi.org/10.1007/s00520-016-3483-9

25. Baker P, Beesley H, Fletcher I, Ablett J, Holcombe C, Salmon P. 'Getting back to normal' or 'a new type of normal'? A qualitative study of patients' responses to the existential threat of cancer. Eur J Cancer Care. 2016;25(1):180-9. https://doi.org/10.1111/ecc. 12274 